\title{
Meeting the energy needs of poultry
}

By Pran Vohra, W. O. Wilson and T. D. Siopes, Department of Avian Sciences, University of California, Davis, California 956r6, USA

A detailed study of the energy needs of poultry is of scientific and economic importance, and is of topical interest, as can be judged from the publication of the proceedings of a symposium held last year on this subject (Morris \& Freeman, 1974).

\section{Measurement and partition of dietary energy} Fig. I.

The partition of gross energy of the diet into its various components is shown in

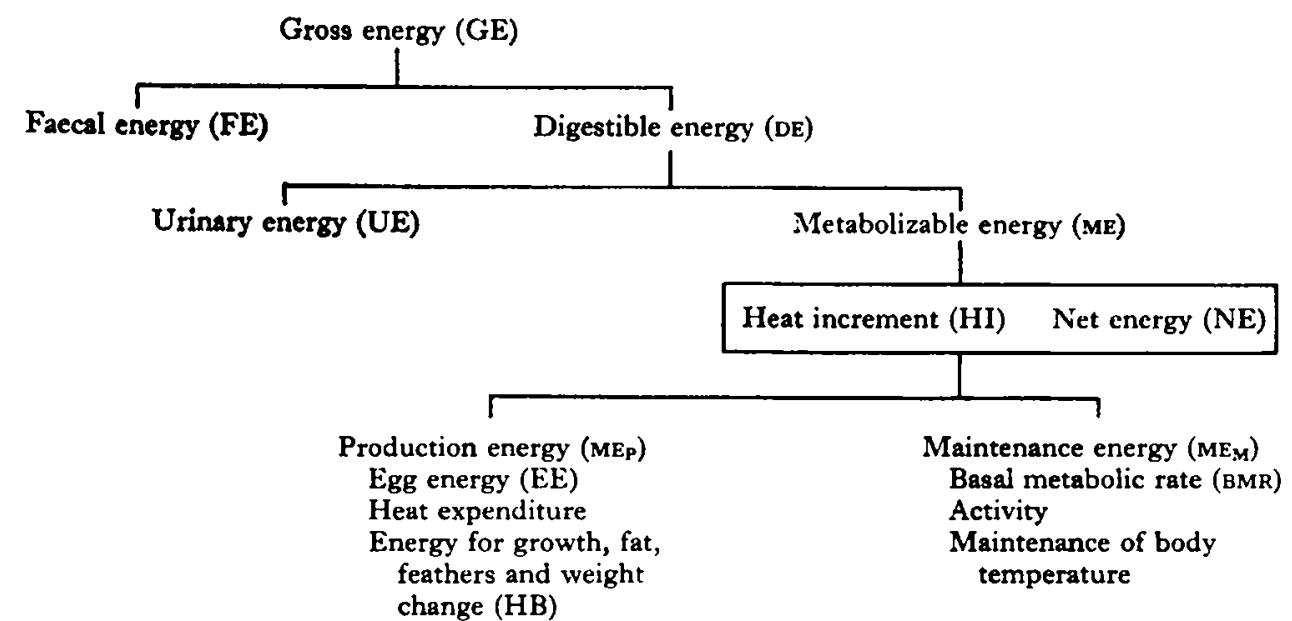

Fig. I. Partition of dietary energy in poultry.

The most popular way is to evaluate the diet in terms of its metabolizable energy (ME) content measured in $\mathrm{kcal}(\mathrm{I} \mathrm{kcal}=4 \cdot 184 \mathrm{~kJ})$. The problems associated with the determination of $M E$ have been recently reviewed by Miller (1974). Unfortunately, the ME of a diet is not always equal to the sum of the ME values of its constituent parts (Vohra, 1972). It is reduced by the presence of toxicants, but is improved by certain fats, owing to the low energy cost of digestion, absorption, transport and deposition of dietary fats relative to the energy requirements for fat synthesis. The topic of carbohydrates and fats as dietary energy sources was reviewed by Annison (1974). The only practical way of predicting the ME of a diet would be from its chemical composition, but no single regression equation fulfills that role as yet. We 
need to develop regression equations to include the positive and the negative contributions of the chemical constituents.

$$
\begin{aligned}
& \mathrm{ME}=(\text { carbohydrate } \times \mathrm{DC} \times \mathrm{GE})+(\mathrm{fat} \times \mathrm{DC} \times \mathrm{GE})+(\text { protein } \times \mathrm{DC} \times \mathrm{GE})- \\
& \quad(\text { effects of toxicants on energy }),
\end{aligned}
$$

where DC and GE are the digestibility coefficient and gross energy of the respective constituents. Actually, a part of dietary ME is lost as heat increment (HI) to give the balance as net energy (NE) for maintenance and production. De Groote (1974) suggests that $\mathrm{NE}$ is a preferable measure and has proposed factors for conversion of $\mathrm{ME}$ of the dietary ingredients to $\mathrm{NE}$. The problems encountered in ME determination would be also applicable for NE. However, NE may have a place in least-cost diet formulations.

\section{Maintenance energy $\left(\mathrm{ME}_{\mathrm{M}}\right)$}

For practical purposes we may define that part of $M E$ which is not utilized for production $\left(\mathrm{ME}_{\mathrm{P}}\right.$ ) as $\mathrm{ME}_{\mathrm{M}}$. It includes basal metabolic rate (BMR), $\mathrm{HI}$ and activitylike components.

BMR of adult homeotherms both large and small can be correlated to their metabolic body size by the following expression: $\mathrm{BMR}(\mathrm{kcal} / \mathrm{d})=A \mathrm{~W}^{k}$ where $A$ is some constant number of $\mathrm{kcal}, \mathrm{W}$ is body-weight $(\mathrm{kg})$, and $k$ is some power to correlate body-weight to surface area. Kleiber ( 1969 ) assigned a value of $70 \mathrm{kcal}(293 \mathrm{~kJ})$ to $A$, and discussed the rationale of using $k=0.75$ to give BMR $(\mathrm{kcal} / \mathrm{d})=70 \mathrm{~W}^{0.75}$.

A major part of the requirement of $\mathrm{ME}_{\mathrm{M}}$ is for BMR and is also expressed in terms of a function of metabolic body size. From the literature, $\mathrm{ME}_{\mathrm{M}}(\mathrm{kcal} / \mathrm{d})$ for laying hens is in the range $99^{-1} 33 \mathrm{~W}^{0.75}$ and the average would be about $100 \mathrm{kcal} / \mathrm{kg}^{0.75}$ (Grimbergen, 1974). The efficiency of utilization of $\mathrm{ME}$ for $\mathrm{ME}_{\mathrm{M}}$ is about $85 \%$ for adult and growing chicks (De Groote, 1974).

\section{Energy for production}

The $\mathrm{ME}_{\mathrm{P}}$ portion of $\mathrm{ME}$ can be utilized for any of the production functions such as growth, deposition of fat, feathers or egg production. The GE of lean body mass may be taken as $1.4 \mathrm{kcal}(5.9 \mathrm{~kJ}) / \mathrm{g}$, of fat as $9.5 \mathrm{kcal}(39.7 \mathrm{~kJ}) / \mathrm{g}$, and of eggs with shell as $1.6 \mathrm{kcal}(6.7 \mathrm{~kJ}) / \mathrm{g}$. The energy associated with a change in body-weight would be between $\mathrm{I}^{\cdot} 4$ and $9 \cdot 5 \mathrm{kcal}\left(5 \cdot 9-39^{\circ} 7 \mathrm{~kJ}\right) / \mathrm{g}$. For practical purposes it may be regarded as $4 \mathrm{kcal}(16.7 \mathrm{~kJ}) / \mathrm{g}$ change in body-weight.

With this information, it is possible to predict the ME requirement for production purposes by assigning an over-all efficiency value of $80 \%$ for $\mathrm{ME}_{\mathrm{p}}$. Grimbergen (1974) estimated the efficiency of utilization of $\mathrm{ME}$ for egg production and fat synthesis at $60 \%$ and $80 \%$, respectively.

\section{Zone of thermal neutrality}

Adult chickens are homeothermic, and consequently the maintenance of normal body temperature takes precedence over any production of eggs or fat. A certain amount of energy is needed for this purpose, depending upon the ambient temperature, and this energy has to be provided by the dietary energy. Animals, in general, have a 
region between the lower and upper critical temperatures which is called the zone of thermal neutrality, in which the fasting metabolic rate (FMR), to differentiate from BMR (animals have some movement), is minimal. On the other hand, the metabolic rate of a fully fed animal at rest is called the resting metabolic rate and is higher than the FMR owing to the thermogenic effect of food. In the thermoneutral zone, the heat production of the animal is constant and heat loss variations maintain the body temperature. But if the ambient temperature falls above or below the thermoneutral range, the heat production increases.

\section{Ideal environmental temperature}

The ideal environmental temperature in a poultry house would be in the zone of thermoneutrality, so that the resting metabolic rate is at its lowest, the energy requirement for maintenance is low, and the maximum amount of $\mathrm{ME}$ is available for production purposes. Actually, the zone of thermoneutrality is not well-defined for avian species, partly because acclimatization may occur. Its existence has been questioned by several investigators (West \& Hart, 1966; Waring \& Brown, 1967; Shannon \& Brown, I 969 ). A temperature range from $5^{\circ}$ to $25^{\circ}$ was most favourable for egg production by White Leghorn hens on the basis of nitrogen retention (Romijn, 1970). Shifts from insulative to metabolic heat regulation were observed with lower temperatures.

In poultry, a continuous decrease of heat production is usually observed with increasing environmental temperatures concomitant with a decrease in food intake and an alteration in behaviour. In the animals which have a well-defined zone of thermal neutrality, food intake and behaviour remain constant during all temperature treatments. An attempt to explain the zone of thermal neutrality on the basis of a combination of feeding, production and activity level of poultry was made by van Es, van Aggelen, Nijkamp, Vogt \& Scheele (1973).

\section{Measurement of FMR}

The FMR can be measured in several ways: ( 1 ) by direct or indirect calorimetry; (2) by energy-balance techniques from body composition as detailed by Farrell (1974); or (3) from certain regression equations as reviewed by Balnave (1974), Grimbergen (1974) and Emmans (1974). Using the expression $\mathrm{FMR}=A \mathrm{~W}^{k}$, estimated values of $\mathrm{I} \cdot 08$ (Tasaki \& Sasa, 1970 ), $\mathrm{I} \cdot 0$ (Grimbergen, 1974), 0.653 (Byerly, 1941 ) as well as 0.75 (Kleiber, 1969) have been given to $k$; and estimates of $68.7-114^{\circ} \mathrm{O}$ kcal (287-477 kJ) have been given for $A$ (Balnave, 1974).

No attention has been paid to the biochemical variations among the members of a flock, or among flocks of the same or different strains, which do exist. These cause differences in metabolic rates, as does the process of egg formation. In general, the estimated values from Kleiber's formula agree reasonably with the values determined by indirect calorimetry from oxygen consumption and carbon dioxide output using the expression of J. R. King as quoted by Romijn (1970):

$$
\operatorname{FMR}(\mathrm{kcal} / \mathrm{d})=3 \cdot 87 \mathrm{I} \mathrm{O}_{2}+\mathrm{I} \cdot \mathrm{I} 94 \mathrm{CO}_{2}-0.048 P \text {, }
$$


where $\mathrm{O}_{2}$ and $\mathrm{CO}_{2}$ are measured in 1 and $P=6 \cdot 25 \times$ urinary $\mathrm{N}$. For practical purposes, $P$ can be assigned a value of zero.

\section{Factors affecting metabolic rates}

The metabolic rates of chickens can be influenced by a number of factors such as age, sex, breed, diurnal rhythms, activity, seasonal variations, feathering, plane of nutrition, environmental temperature, diet and feeding regimen, acclimatization, and egg formation. Some of these factors have been discussed in some detail by Balnave (1974).

The literature values indicate that FMR of laying hens vary from about $6 \mathrm{I}$ to I $17 \mathrm{kcal}(255-490 \mathrm{~kJ}) / \mathrm{kg}^{0.75}$ per $\mathrm{d}$ while the corresponding values for maintenance requirements were about $82-134 \mathrm{kcal}(343-56 \mathrm{r} \mathrm{kJ}) / \mathrm{kg}^{0.75}$ per d. Since about $80 \%$ of the $M E_{M}$ requirement is for FMR, any factors influencing FMR, naturally, would influence the maintenance requirements.

For example, FMR of poorly feathcred cockerels is 2.5 times that of feathered ones at $22^{\circ}\left(O^{\prime}\right.$ Neill, Balnave \& Jackson, 197I), suggesting higher maintenance requirements of such birds.

Acclimatization of FMR to higher temperatures is more rapid than to low temperatures (Harrison \& Biellier, I 969). The following regression equation has been suggested to fit FMR against temperature from $-5^{\circ}$ to $40^{\circ}$ (van Kampen, 1974):

FMR $\left(\mathrm{kcal} / \mathrm{kg}^{0.73}\right.$ per d) $=0.0058 \mathrm{~T}_{\mathrm{a}}{ }^{2}-4.517 \mathrm{~T}_{\mathrm{a}}+\mathrm{I} 92$,

where $\mathrm{T}_{\mathrm{a}}$ is ambient temperature in ${ }^{\circ} \mathrm{C}$.

As the ambient temperature increased from $21^{\circ}$ to $29^{\circ} 5^{\circ}$, still within the accepted thermoneutral zone, FMR of White Leghorn hybrids decreased from 106 to 96 $\mathrm{kcal} / \mathrm{kg}^{0.75}$ per $\mathrm{d}$ (Waring \& Brown, 1967) implying a decrease in maintenance requirements. This would lead to a reduction in energy intake for the same status of production at $29.5^{\circ}$ and $31^{\circ}$, but not at $16^{\circ}$ and $28^{\circ}$. Distinct populations with different metabolic rates were observed in the same flock by Tasaki \& Sakurai (1969).

The further interactions between the factors lead to the complexity of the problem of prediction of FMR.

\section{Energy needs for egg production}

On the basis of the above comments, the energy requirements of laying hens can be expressed in the following general terms:

$\mathrm{ME}$ requirement $=\mathrm{ME}_{\mathrm{M}} \pm$ energy associated with change in body-weight $(a \Delta \mathrm{W})+$ energy associated with daily egg mass produced $(b \mathrm{E})$.

Byerly (194I) developed the following equation to estimate the food needs of hens of different body-weights and rates of egg production:

$F=0.523 W^{0.653} \pm I \cdot 126 \Delta W+I \cdot 135 E$, where food consumption (F), average body-weight $(\mathrm{W})$, daily change in body-weight $(\Delta \mathrm{W})$ and egg mass per hen per $\mathrm{d}(\mathrm{E})$ were all in $\mathrm{g}$. On the supposition that diets of that time contained $2900 \mathrm{kcal}$ ( $12 \cdot 13$ $\mathrm{MJ}$ ) $\mathrm{ME} / \mathrm{kg}$, Combs (1962) rewrote Byerly's expression as follows:

$$
\mathrm{ME}(\mathrm{kcal} / \mathrm{d})=\mathrm{I} \cdot 5 \mathrm{r} 7 \mathrm{~W}^{0.653} \pm 3.265 \Delta \mathrm{W}+3.292 \mathrm{E} .
$$


Janssen (1970) used the following regression equation for caged layers:

$$
M E(\mathrm{kcal} / \mathrm{d})=0.676 \mathrm{~W}^{0.75}+2.866 \mathrm{E}+\mathrm{I} 9 \text {. }
$$

If $\mathrm{W}$ is expressed in $\mathrm{kg}$, and the values of $\mathrm{I} \cdot 6 \mathrm{kcal}(6.7 \mathrm{~kJ}) / \mathrm{g}$ and $4 \mathrm{kcal}(\mathrm{I} 6.7 \mathrm{~kJ}) / \mathrm{g}$ are assigned to egg energy (EE) and body energy (BE), the regression equations of various investigators can be compared as in Table 1 .

Table 1. Estimates of the daily metabolizable energy (ME) intake (kcal) of laying hens calculated for $a 2 \mathrm{~kg}$ hen producing an egg containing $80 \mathrm{kcal}$ energy, neglecting any change in body-weight

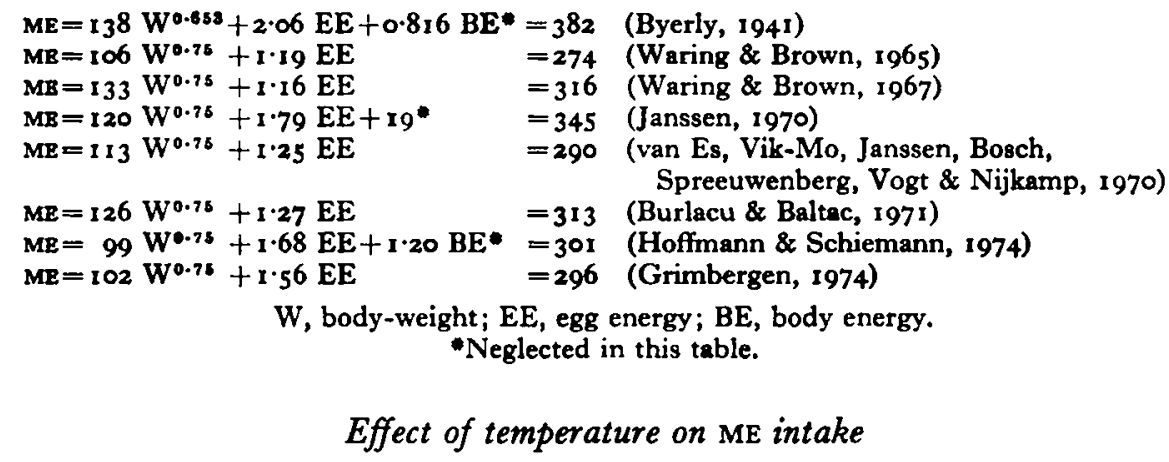

The food consumption was markedly influenced by both the ambient temperature and the dietary energy. Some results from one of our recent experiments are given in Table 2.

The estimated values from Byerly's equation or from calorimetric studies were in fair agreement for layers maintained between $5^{\circ}$ and $24^{\circ}$, but were $5-15 \%$ low at temperatures below $5^{\circ}$, and exceeded the observed values by even $100 \%$ above $294^{\circ}$ (Longhouse, Ota \& Ashby, 1960). At temperatures ranging from $-5^{\circ}$ to $30^{\circ}$, a reduction of about $\mathrm{r} \cdot 6 \%$ in food intake occurred per ${ }^{\circ} \mathrm{C}$ increase in ambient temperature, according to a review by Payne ( 1967 ). Above $30^{\circ}$ the decrease is even greater (Wilson, 1949). A number of regression equations have been proposed to correlate energy intake with production at different temperatures, as shown in Table 3 .

However, when daily ME intake of White Leghorn hybrids is corrected to constant metabolic body-weight, the relationship is curvilinear within the temperature range

Table 2. The effect of giving diets with two levels of metabolizable energy (ME) to Leghorn-type laying hens on their performance over $168 d$

Environmental temperature...

Diet energy (MR) ( $\mathrm{MJ} / \mathbf{k g})$

Mean initial body-weight (kg)

Mean final body-weight (kg)

Egg production (\%hens/d)

Egg weight (g)

Food consumption (g/d per hen)

ME intake (kJ/d)

(kcal/d)

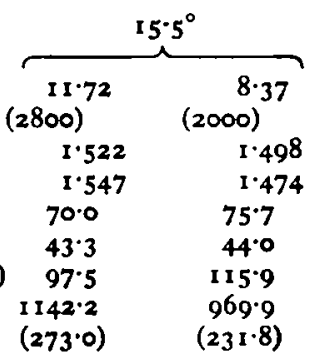

$(273 \cdot 0)$

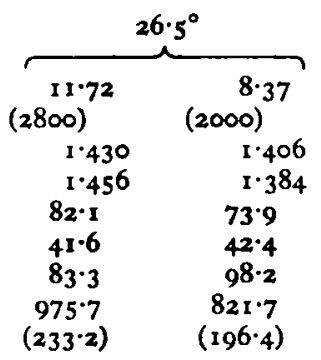


of $21^{\circ}-38^{\circ}$ (Smith, 1971 ). As the temperatures increased, the energy intake decreased at a faster rate than heat production and less energy was available for egg production, leading to a reduction in egg production or egg size or both. Little effect of temperature on egg production was observed in the range $15^{\circ}-27^{\circ}$, but production was depressed at $30^{\circ}$. The food consumption does decrease by about $14 \%$ at $27^{\circ}$ compared to $15^{\circ}$, but this may not be an economic advantage if the nutrients have to be concentrated in the diet (Marsden, Wethli, Kinread \& Morris, 1973). The egg production of light hybrid layers was maintained at about $88 \%$ when the diets contained 2.64 or $3.35 \mathrm{kcal}$ ( I I or $14 \mathrm{~kJ}$ ) ME/g at fluctuating temperatures of $18^{\circ}-30^{\circ}$, but was $10 \%$ less for the lower-energy group at a constant temperature of $30^{\circ}$ (Mowbray \& Sykes, 1971).

Table 3. Regression equations to correlate metabolizable energy (ME) intake (kcalld) with ambient temperature in poultry

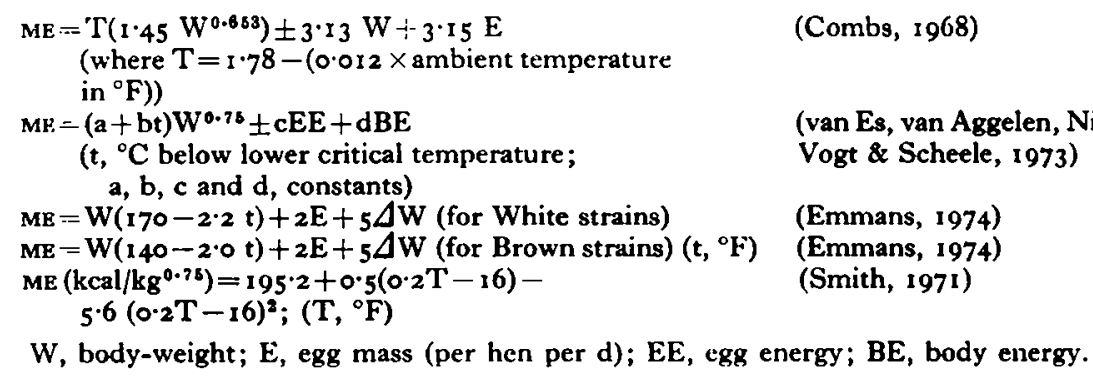

\section{Energy requirements of broilers}

The biological and economic responses of broilers to dietary energy concentration have been analysed by C. Fisher \& B. J. Wilson (personal communication) and suggestions have been given to enable the producer and formulators to make their own rational decisions on the basis of local conditions rather than provide accurate estimates of optimum energy level for general use.

The results of Deaton \& Reece (1970) indicate that broilers reared at the low temperature cycle $\left(\mathrm{I} \cdot 7^{\circ}-18.3^{\circ}\right)$ were $0.12 \mathrm{~kg}$ heavier than those raised at $18.3^{\circ}-35^{\circ}$, but also consumed $0.68 \mathrm{~kg}$ more food, making them less efficient to grow. Relative humidity had no effect on this performance below $26 \cdot 7^{\circ}$.

\section{Restricted feeding of layers}

Layers can adjust their energy intake over a range of dietary energy levels, but tend to overconsume diets more concentrated in ME when offered on a free-choice basis (Morris, 1968). This leads to an increase in body-weight and maintenance requirement. A number of reports do suggest that the net utilization of energy by layers can be improved by restricting the energy intake to levels below those on a free-choice basis. This topic was covered in some detail by Snetsinger \& Zimmerman (1974). The amino acids, vitamins and minerals of restricted diets have to be increased to prevent any deficiencies occurring during dietary restriction. If the restriction is 
about $10 \%$, the production can be maintained, but the egg size is depressed by about I g. The choice of restricting dietary intakes, and of methods of accomplishing this, must be judged on an economic basis, and this favours adjusting consumption to that of a peer group, but as yet no hard and fast rules can be established.

\section{REFERENCES}

Annison, E. F. (1974). In Energy Requirements of Poultry, p. 135 [T. R. Morris and B. M. Freeman, editors]. Edinburgh: Longman Group Ltd.

Balnave, D. (1974). In Energy Requirements of Poultry, p. 25 [T. R. Morris and B. M. Freeman, editor8]. Edinburgh: Longman Group Ltd.

Burlacu, G. \& Baltac, M. (1971). F. agric. Sci., Camb. 77, 405.

Byerly, T. C. (194I). Bull. Md. agric. Exp. Stn no. A1.

Combs, G. F. (1962). In Nutrition of Pigs and Poultry, p. 141 [J. T. Morgan and D. Lewis, editors]. London: Butterworths.

Combs, G. F. (1968). Proc. Univ. Md Nutr. Conf. p. 86.

Deaton, J. W. \& Reece, F. N. (1 970). Feedstuffs, Minneap. 42, 5.

De Groote, G. (1974). In Energy Requirements of Poultry, p. I13 [T. R. Morris and B. M. Freeman, editors]. Edinburgh: Longman Group Ltd.

Emmans, G. C. (1974). In Energy Requirements of Poultry, p. 79 [T. R. Morris and B. M. Freeman, editors]. Edinburgh: Longman Group Ltd.

Farrell, D. J. (1974). In Energy Requirements of Poultry, p. I [T. R. Morris and B. M. Freeman, editors]. Edinburgh: Longman Group Ltd.

Grimbergen, A. H. M. (1974). In Energy Requirements of Poultry, p. 61 [T. R. Morris and B. M. Freeman, editors]. Edinburgh: Longman Group Ltd.

Harrison, P. C. \& Biellier, H. V. (1969). Poult. Sci. 48, 1034.

Hoffmann, L. \& Schiemann, R. (1974). Arch. Tierernähr. 23, 105.

Janssen, W. M. M. A. (1970). In Voedernormen voor de Landbouwhuisdiern en Voederwaarde der Veevoeder: Verkorte Tabel, 26 druk. Wageningen: Centraal Veevoederbureau.

Kleiber, M. (1969). Publs. Eur. Ass. Anim. Prod. no. 12, p. 505.

Longhouse, A. D., Ota, H. \& Ashby, W. (1960). Y. agric. Engng 41, 567.

Marsden, A., Wethli, E., Kinread, N. \& Morris, T. R. (1973). Wld's Poult. Sci. J. 29, 286.

Miller, W. S. (1974). In Energy Requirements of Poultry, p. 91 [T. R. Morris and B. M. Freeman, editors]. Edinburgh: Longman Group Ltd.

Morris, T. R. (1968). Br. Poult. Sci. 9, 285.

Morris, 'T. R. \& Freeman, B. M. (editors) (1974). Energy Requirements of Poultry. Edinburgh: Longman Group Ltd.

Mowbray, R. M. \& Sykes, A. H. (1971). Br. Poult. Sci. 12, 25.

O'Neill, S. J. B., Balnave, D. \& Jackson, N. (1971). Y. agric. Sci., Camb. 77, 293.

Payne, C. G. (1967). In Environmental Control in Poultry Production, p. 40 [T. C. Carter, editor]. London: Oliver \& Boyd.

Romijn, C. (1970). Proc. Wld's Poult. Congr., Madrid 2, 439.

Shannon, D. W. F. \& Brown, W. O. (1969). Br. Poult. Sci. ro, 13.

Smith, A. J. (1971). Feedstuffs, Minneap. 43, 24.

Snetsinger, D. \& Zimmerman, R. (1974). Feedstuffs, Minneap. 46, 28.

Tasaki, I. \& Sakurai, H. (1969). Mem. Lab. Anim. Nutr., Nagoya Univ. no. 4.

Tasaki, I. \& Sasa, Y. (1970). Publs Eur. Ass. Anim. Prod. no. 13 , p. 197.

van Es, A. J. H., van Aggelen, D., Nijkamp, H. J., Vogt, J. E. \& Scheele, C. W. (1973). Z. Tierphysiol. Tierernähr. Futtermittelk. 32, 121.

van Es, A. J. H., Vik-Mo, L., Janssen, H., Bosch, A., Spreeuwenberg, W., Vogt, J. E. \& Nijkamp, H. J. (1970). Publs Eur. Ass. Anim. Prod. no. 13, p. 201.

van Kampen, M. (1974). In Energy Requirements of Poultry, p. 47 [T. R. Morris and B. M. Freeman, editors]. Edinburgh: Longman Group Ltd.

Vohra, P. (1972). Wld's Poult. Sci. F. 29, 204.

Waring, J. J. \& Brown, W. O. (1965). F. agric. Sci., Camb. 65, 139.

Waring, J. J. \& Brown, W. O. (1967). J. agric. Sci., Camb. 68, 149.

West, G. C. \& Hart, J. S. (1966). Physiol. Zoö. 39, 171.

Wilson, W. O. (1949). Poult. Sci. 28, 581 . 